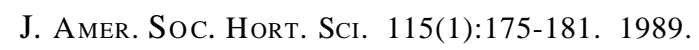

\title{
Productivity Under Shade in Hawaii of Five Crops Grown as Vegetables in the Tropics
}

\author{
Xenia Y. Wolff ${ }^{1}$ and Robert R. Coltman ${ }^{2}$ \\ Department of Horticulture, University of Hawaii, Honolulu, HI 96822 \\ Additional index words. eggplant, Solanum melongena, soybean, Glycine max, peanut, Arachis hypogea, sweet potato, \\ Ipomoea batatas, lettuce, Lactuca sativa
}

Abstract. 'Waimanalo Long' eggplant (Solanum melongena L.), 'Kahala' soybean [Glycine max (L.) Merrill], 'Jumbo Virginia' peanut (Arachis hypogea L.), 'Waimanalo Red' sweet potato [Ipomea batatas (L.) Lam.], and 'Green Mignonette' semihead lettuce (Lactuca sativa L.) were field-grown in two seasons at Waimanalo, Oahu, Hawaii, in the open sun and with four artificially produced levels of shade $(30 \%, 47 \%, 63 \%$, and $73 \%)$. Yields and vegetative growth of eggplant, soybean, peanut, and sweet potato decreased linearly with increasing shade levels. Compared to unshaded controls, yields of semihead lettuce increased significantly under $30 \%$ shade in Fall 1986. During Spring 1987, lettuce yields were reduced only slightly from unshaded levels by increasing shade up to $47 \%$. Leaf areas of index leaves of eggplant, soybean, and lettuce were similar to unshaded controls as shade intensity increased, while leaf dry weight decreased under shade. By comparison, both leaf area and leaf dry weight of peanut index leaves decreased as shade increased. Leaf area and leaf dry weight of sweet potato did not respond to shading. The results indicate that, of the five crops studied, only lettuce can be grown successfully under lightly shaded conditions and still receive enough radiant energy for maximum photosynthesis and yields.

The decreasing availability of good agricultural land and the high costs of land and agricultural inputs are becoming serious limiting factors to increased agricultural production in various areas, especially in the tropics (Stelly, 1983). These problems necessitate the development of agricultural systems that use land more intensively without adversely affecting quality or yield. Mixed-cropping, the practice of growing several crops on the same piece of land, either simultaneously or in succession, is

Received for publication 26 Sept. 1988. Journal Series no. 3325 of the Hawaii Institute of Tropical Agriculture and Human Resources. X.Y.W. was supported by a grant from the Resource Systems Institute, East-West Center. The cost of publishing this paper was defrayed in part by the payment of page charges. Under postal regulations, this paper therefore must be hereby marked advertisement solely to indicate this fact.

${ }^{\mathrm{I}}$ Former graduate student. Present address: USDA/ARS, Center for Small Farm Research, Southern Univ., P.O. Box 11170, Baton Rouge, LA 70813.

${ }^{2}$ Associate Professor. an intensive method of land-use with potential for increasing food production (ICRISAT, 1981). Shading among plants that occurs when crops of different heights are grown together, or when short-stature crops are grown within orchard stands, becomes a major consideration in a mixed-crop situation.

Studies of the effects of reduced photosynthetic photon flux (PPF) on vegetable crop productivity have shown great variability in responses of leaf and plant morphology, productivity, and physiology among and within crop species. These responses depend on several factors, including cultivar, the quality and quantity of radiation under which the crop is grown, the light saturation point of the leaf canopy, and other environmental conditions, especially temperature (Bowes et al., 1972; Ketring, 1984; Knight and Mitchell, 1983; Martin, 1985; Smith et al., 1984).

Under tropical and subtropical conditions, yields and quality 
of some vegetable crops have been improved by shading. For example, tomatoes, spinach, and lettuce yielded more under reduced PPF conditions ranging from $15 \%$ to $50 \%$ shade in regions with high light intensities (Glenn et al., 1984; Mattei et al., 1973; Smith et al., 1984). Therefore, both mixed cropping and crop production under shade structures have potential for increasing productivity of some vegetable crops in the tropics and subtropics. This study was undertaken to evaluate the effects of shade on the productivity of five important crops grown as vegetables under tropical conditions in Hawaii.

\section{Materials and Methods}

Field preparation. A 0.12-ha field at Waimanalo Agricultural Research Station, Oahu, Hawaii, was prepared for planting in Summer 1986. Local recommendations for soil preparation and fertilization for eggplant, soybean, peanut, sweet potato, and lettuce were followed at all times (Beard et al., 1980; Hartmann et al., 1978; Tanaka and Sakuoka, 1973). Dolomitic limestone (4260 $\mathrm{kg} \cdot \mathrm{ha}^{-1}$ ) and triple superphosphate (466 kg P/ha) were added to the Typic Haplustoll subgroup type soil to raise the $\mathrm{pH}$ from 5.4 to 5.9 and raise the soil solution $\mathrm{P}$ concentration to $0.3 \mu \mathrm{g} \cdot \mathrm{ml}^{-1}$ (Nishimoto et al., 1977). An equivalent of 60 $\mathrm{kg} \mathrm{N} / \mathrm{ha}$ was added to the field as urea. For the Spring 1987 trial, the field was reworked and refertilized with $215 \mathrm{~kg} \mathrm{~N}, 94$ $\mathrm{kg} \mathrm{P}$, and $175 \mathrm{~kg} \mathrm{~K}$ per ha.

Experimental design. Shadecloth canopies were erected over each of 15 plots. Supports were $10 \mathrm{~cm} \times 10 \mathrm{~cm} \times 3-\mathrm{m}$ vertical wooden beams set at the corners of $7.6 \times 9.1-\mathrm{m}$ plots and anchored $1 \mathrm{~m}$ deep in the soil in a grid-shaped pattern. Galvanized $0.6-\mathrm{cm}$-diameter wire rope was strung between the beams $1.8 \mathrm{~m}$ above the ground. Grometted panels of commercially available, black $30 \%, 47 \%, 63 \%$, and $73 \%$ shadecloths were suspended form the wire rope. Three replicates of each shade level and unshaded controls were completely randomized in the field. Maximum and minimum air temperatures, precipitation, and total solar irradiance (SI) under full-sun were monitored daily using a LI-COR (Lincoln, Neb.) LI-1200 datalogger equipped with a thermistor temperature sensor, tipping-bucket rain gauge, and an LI-200SA pyranometer.

Total SI $\left(\mathrm{MJ} \cdot \mathrm{m}^{-2}\right)$ received between planting and harvest for each crop was converted to total photosynthetically active radiation (PAR, mol. $\mathrm{m}^{-2}$ ) using the conversion for sunlight determined by Meek et al. (1984). Total PAR, rather than total
SI, was used in discussing yield results after confirming with a LICOR LI-191SA Line Quantum Sensor that PAR was directly proportional to the level of shade used. Total PAR received by each crop was used instead of percent shade because total PAR received varied among crops and seasons, and percent shade as a predictor variable would not reflect these differences. Because of seasonal variation in light intensity and duration, especially in tropical areas where year-round production is possible, optimum shading may vary for crops produced at different times of the year.

Cultural conditions. Five 4-m-long rows of 'Waimanalo Long' eggplant, and four 4-m-long rows each of 'Kahala' soybean, 'Jumbo Virginia' peanut, 'Waimanalo Red' sweet potato, and 'Green Mignonette' lettuce, known locally as "Manoa lettuce", were grown simultaneously in each plot. The area required per eggplant plant is much greater than that required by the other crops, thus five, instead of four, rows of this crop were grown to provide a sufficient number of harvestable plants. Crop subplots were randomized within each shade level plot to minimize border effects. Data were collected only from the two or three internal rows in crop subplots. The study was carried out twice, from Sept. 1986 to Feb. 1987 and from Feb. to July 1987.

Eggplant was seeded 10 Aug. 1986 (Fall 1986) and 8 Jan. 1987 (Spring 1987) into transplant flats with 5-cm-diameter, 100-ml cells that contained a mixture of 1 peat : 1 vermiculite (v/v) amended with $271 \mathrm{~g}$ dolomite and $139 \mathrm{~g}$ gypsum per $\mathrm{m}^{3}$. Micronutrients were incorporated as $33 \mathrm{~g}$ Micromax per $\mathrm{m}^{3}$ and slow release macronutrients as $1109 \mathrm{~g}$ of $19 \mathrm{~N}-2.6 \mathrm{P}-9.9 \mathrm{~K}$ Osmocote (Sierra Chemical, Milpitas, Calif.) to give $211 \mathrm{~g} \mathrm{~N}, 29$ $\mathrm{gP}$, and $111 \mathrm{~g} \mathrm{~K}$ per $\mathrm{m}^{3}$ Dates of transplanting eggplant seedlings and sweet potato cuttings, and of direct-seeding soybeans, peanuts, and lettuce, their harvest dates, production practices, and experimental plot sizes are presented in Table 1 . The final spacing (Table 1) was achieved by thinning the direct-seeded crops 3 weeks after planting. All plants were fertilized by banding $215 \mathrm{~kg} \mathrm{~N}, 94 \mathrm{~kg} \mathrm{P}$, and $175 \mathrm{~kg} \mathrm{~K}$ per ha 4 weeks after planting. The plots were drip-irrigated three times per week at an average rate of $0.5 \mathrm{~cm} \cdot$ day $^{-1}$ to supplement natural rainfall. All plots were irrigated equally regardless of shade level. Very heavy rains during Fall 1986, especially during the week of 9 Nov. (Fig. 1), eliminated the need for subsequent irrigation.

Leaf area and dry weight measurements. To determine characteristics of leaf morphology as influenced by shading, three

Table 1. Planting and harvest dates and production practices for 'Waimanalo Long' eggplant, 'Kahala' soybean, 'Jumbo Virginia' peanut, 'Waimanalo Red' sweet potato, and 'Green Mignonette' lettuce grown during Fall 1986 and Spring 1987.

\begin{tabular}{|c|c|c|c|c|c|c|c|c|}
\hline \multirow[b]{2}{*}{ Crop } & \multicolumn{2}{|c|}{ Planting date } & \multicolumn{2}{|c|}{ Harvest date } & \multirow{2}{*}{$\begin{array}{l}\text { No. } \\
\text { plants } \\
\text { /row }\end{array}$} & \multicolumn{2}{|c|}{ Spacing } & \multirow{2}{*}{$\begin{array}{l}\text { Plot } \\
\text { size } \\
\left(\mathrm{m}^{2}\right)\end{array}$} \\
\hline & $\begin{array}{c}\text { Fall } \\
1986 \\
\end{array}$ & $\begin{array}{c}\text { Spring } \\
1987\end{array}$ & $\begin{array}{c}\text { Fall } \\
1986^{2}\end{array}$ & 1987 & & $\begin{array}{l}\text { Between } \\
\text { rows }(\mathrm{m})\end{array}$ & $\begin{array}{c}\text { Between } \\
\text { plants (m) }\end{array}$ & \\
\hline Eggplanty & 26 Sept. & 17 Feb. & $\begin{array}{l}18 \text { Nov. }^{\mathbf{x}} \\
27 \text { Jan. }^{w}\end{array}$ & $\begin{array}{l}21 \text { Apr. }^{x} \\
9 \text { June }^{w}\end{array}$ & 5 & 0.7 & 0.7 & 4.8 \\
\hline Soybean & 2 Oct. & 17 Feb. & $13 \mathrm{Jan}$. & 26 May & 35 & 0.7 & 0.1 & 5.4 \\
\hline Peanut & 2 Oct. & $17 \mathrm{Feb}$ & 3 Feb. ${ }^{\vee}$ & 8 July $^{v}$ & 20 & 0.6 & 0.2 & 9.7 \\
\hline Sweet potatoz & 3 Oct. & 24 Feb. & $\begin{array}{l}27 \text { Nov. }^{x} \\
28 \text { Jan.w }^{2}\end{array}$ & $\begin{array}{l}14 \text { May }^{x} \\
25 \text { June }^{w}\end{array}$ & 12 & 0.9 & 0.3 & 13.0 \\
\hline Lettuce & 2 Oct. & 22 Feb. & 18 Nov. & 14 Apr. & 15 & 0.3 & 0.2 & 2.2 \\
\hline
\end{tabular}

${ }^{2}$ Dates are 1987, with exception of eggplant and sweet potato first harvest dates and lettuce, which are 1986. sMultiple harvests.

"First harvest date.

"Final harvest date.

'Full-sun harvest date. 


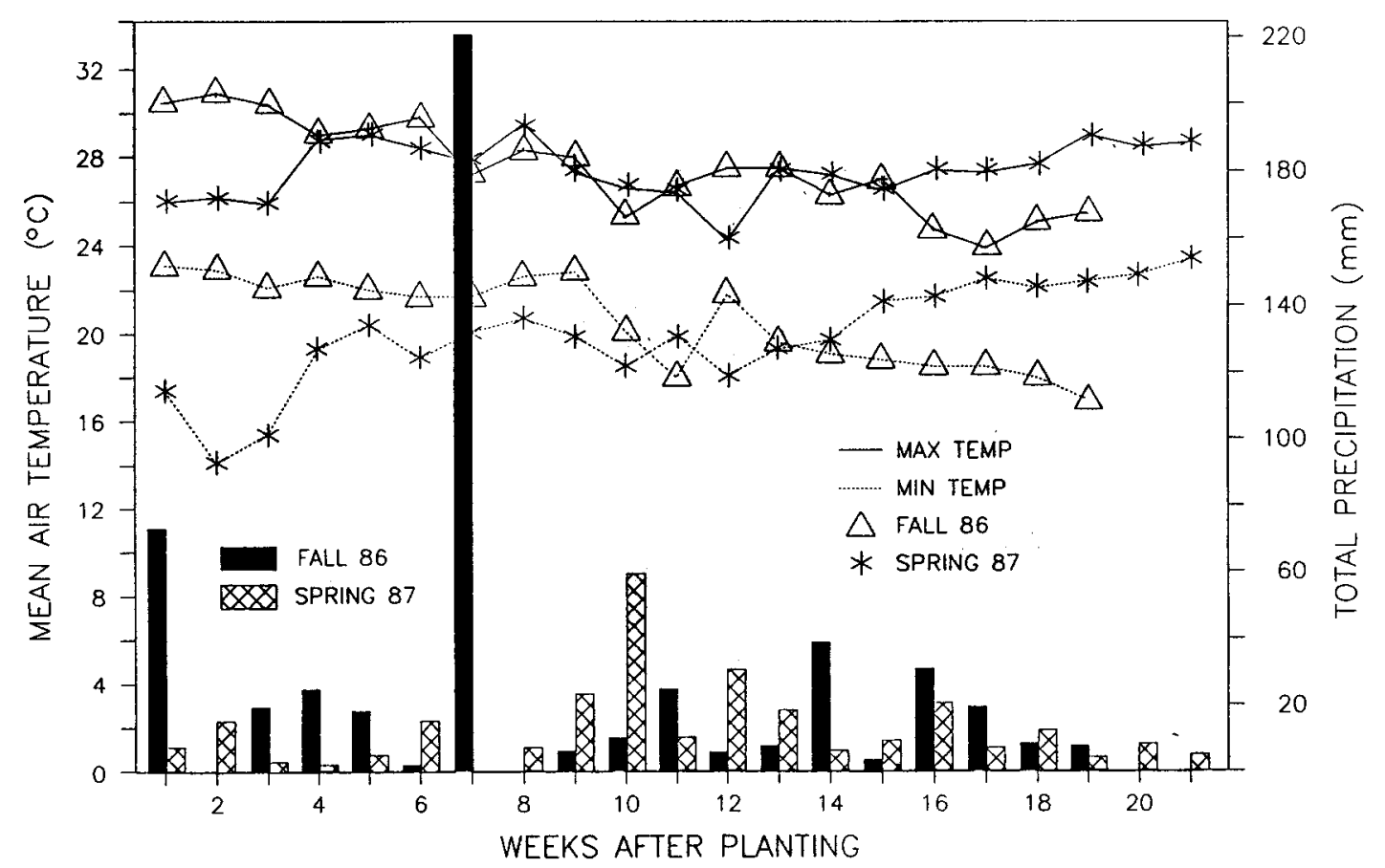

Fig. 1. Mean weekly minimum and maximum air temperatures and total weekly precipitation during Fall 1986 and Spring 1987.

young, fully expanded leaves (index leaves) per subplot were collected for leaf area and leaf dry weight measurements; specific leaf area (SLA = index leaf area/index leaf dry weight) was calculated. Eggplant, soybean, and peanut index leaves were collected at anthesis, sweet potato index leaves at the beginning of root bulking, and lettuce index leaves at harvest maturity. Leaf area was measured using a LI-COR LI-3100 area meter. Leaves were dried for at least $48 \mathrm{hr}$ at $65 \mathrm{C}$ before weighing.

Photosynthesis data. Rates of net photosynthesis (Pn) in two young, fully expanded leaves were determined in situ in all subplots using a LI-COR LI-6000 portable photosynthesis system equipped with a quantum sensor (LI190-SA) to measure photosynthetic photon flux (PPF, $\mu \mathrm{mol} \cdot \mathrm{s}^{-1} \cdot \mathrm{m}^{-2}$ ). Data were taken during the spring planting only. PPF for eggplant, soybean, and peanut was measured at anthesis, for sweet potato at the beginning of root bulking, and for lettuce at harvest maturity. The leaf-leaf chamber orientation during the measurements corresponded to the premeasurement leaf angle. Ten readings $6 \mathrm{sec}$ apart per measurement were taken between 1000 and $1400 \mathrm{HR}$ during bright sky conditions. A continuous range of PPF and Pn rates resulted from cloud cover varying while measurements were made among the plots.

Harvest procedures. Mature eggplant fruit were harvested, counted, and weighed fresh weekly. The durations of the harvests for the Fall 1986 and Spring 1987 plantings were 11 and 8 weeks, respectively. Soybeans were harvested when $50 \%$ of the plants had $95 \%$ of their pods brown (harvest maturity) (Jones, 1985). The plants were dried completely, threshed, and total dry seed weights measured. Peanuts were harvested at harvest maturity $(50 \%$ of the plants with two-thirds to three-fourths of all developed pods having brownish testa or pericarp coloration) (Jones, 1985). Pods and seeds were cleaned and dried and total pod plus seed dry weights recorded.

Successive, destructive harvests of entire sweet potato plants were made beginning 8 weeks after planting in Fall 1986, with

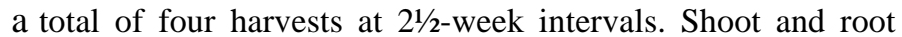
fresh weights and the number of roots from six plants were measured at each harvest. Vine length of three randomly selected vines/subplot also was determined. Because beginning of bulking first occurred $\approx 11$ weeks after cuttings were planted in Fall 1986, the first harvest in Spring 1987 was made at this time. Subsequent harvests were scheduled 2 weeks apart to obtain four harvests in the same total growing time as in Fall 1986.

Successive, destructive harvests of lettuce were made weekly, beginning 4 weeks after seeding (Fall 1986) and 5 weeks after seeding (Spring 1987) to observe differences in growth rates and physiological maturity between shade treatments. At each

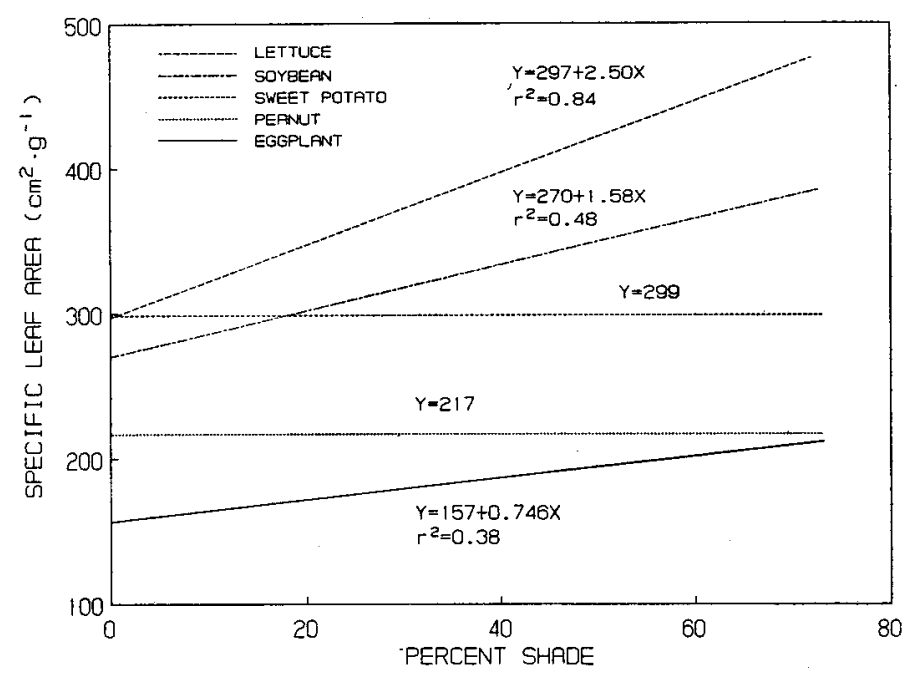

Fig. 2. Specific leaf area of 'Green Mignonette' lettuce at harvest maturity, 'Kahala' soybean, 'Waimanalo Red' sweet potato at beginning of root bulking, 'Jumbo Virginia' peanut at anthesis, and 'Waimanalo Long' eggplant averaged over both experiments as a function of percent shade. 
Table 2. Vine length, plant top fresh weight, cumulative root number, and mean single root weight of 'Waimanalo Red' sweet potato grown during Fall 1986 and Spring 1987 under five shade levels. ${ }^{z}$

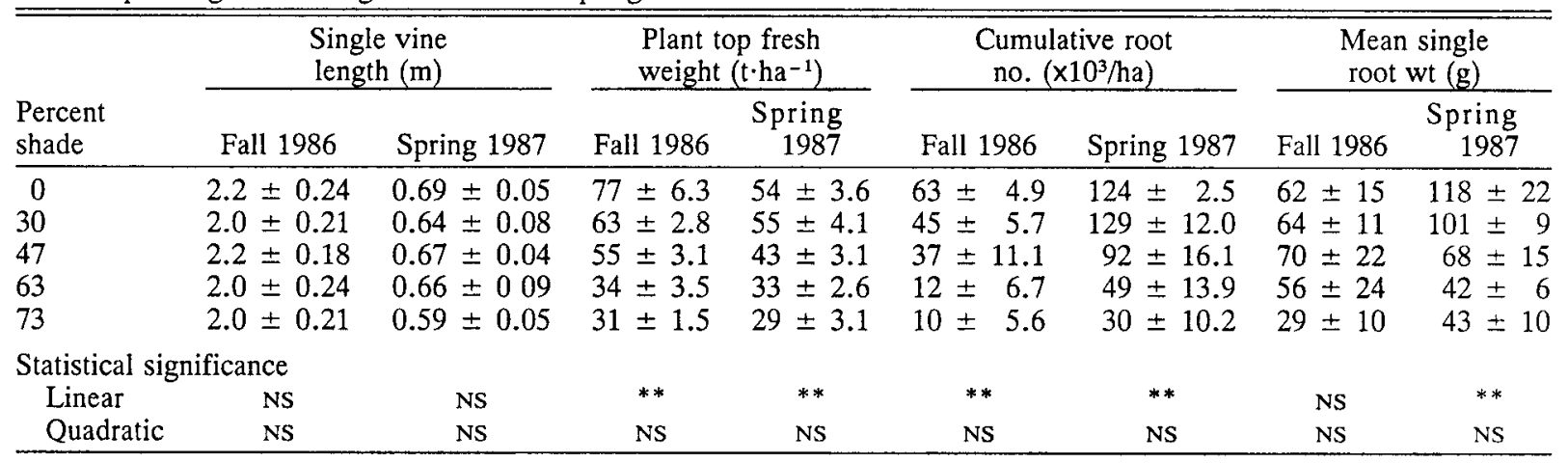

${ }^{z}$ Means $\pm 95 \%$ confidence interval.

NS,**Nonsignificant or significant at $P=0.01$, respectively.

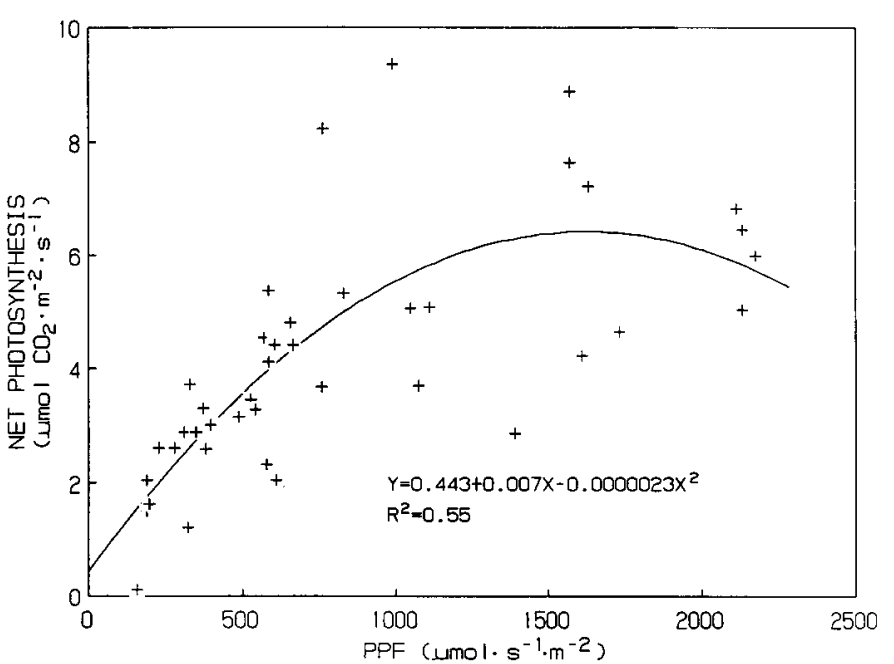

Fig. 3. Photosynthetic rate of 'Green Mignonette' lettuce at harvest maturity during Spring 1987 as a function of photosynthetic photon flux (PPF).

harvest, a total of four lettuce heads was cut from the two center rows of each subplot and total head fresh weights measured. The criterion for harvest maturity was the development of compact heads.

Data from each crop were analyzed independently from the thrice-replicated completely randomized design; no comparisons among crops were made. Best-fit curves for leaf area, dry weight, harvest yield, and photosynthetic rate vs. shade, total PAR, or PPF were calculated using polynomial models with the Systems for Statistics (Wilkinson, 1986). Only coefficients significant at $P<0.05$ were retained in the models.

\section{Results and Discussion}

Leaf morphology. Specific leaf area of eggplant, soybean, and lettuce increased as percent shade increased (Fig. 2) because index leaf areas remained constant while leaf dry weights declined as shade increased. This increase in SLA with increasing shade was observed in both seasons with these three crops. The production of broad, thin leaves is a common adaptive strategy of plants growing in natural shady environments, presumably because it increases the light interception possible per unit of structural biomass (Boardman, 1977).

Peanut and sweet potato SLAs were unaffected by shade in both seasons, but for different reasons. Peanut index leaf area and dry weight were both significantly reduced by shading, while index leaf area and dry weight of sweet potato were unchanged over all shade levels tested. Individual sweet potato vine length also was not affected by shade, while total plant top fresh weight was significantly reduced under shade in both experiments (Table 2). Because shade had no effect on vine length, but a significant negative effect on plant top fresh weight, it was concluded that the total number vines per plant was reduced by shading. Visual observations supported this conclusion, although no data on vine number were taken.

Photosynthetic rates. Net carbon assimilation rates of eggplant, soybean, peanut, and sweet potato increased linearly up to the highest PPF observed with full sunlight $€$. $200 \mu \mathrm{mol} \cdot \mathrm{s}^{-1} \cdot \mathrm{m}^{-2}$ ) (data not shown). Maximum photosynthetic rates for eggplant, soybean, and sweet potato were $\approx 18 \mu \mathrm{mol} \mathrm{CO}_{2} / \mathrm{m}^{2}$ per sec and for peanut $\approx 22 \mu \mathrm{mol} \mathrm{CO}_{2} / \mathrm{m}^{2}$ per sec at full sunlight.

Lettuce responded differently to increasing light levels, with maximum $\mathrm{Pn}$ of $\approx 6 \mu \mathrm{mol} \mathrm{CO} / \mathrm{m}^{2}$ per sec reached at about twothirds of full sunlight $\left(1500 \mu \mathrm{mol} \cdot \mathrm{s}^{-1} \cdot \mathrm{m}^{-2}\right)$ (Fig. 3). Conclusions about the effects of higher light intensities on lettuce Pn are not possible from these data due to high variability. Light saturation of lettuce at half of full sunlight and decreased photosynthetic rates at higher light intensities have been reported previously (Mattei et al., 1973).

Development and yields. Cumulative eggplant fruit yields from the 11 weekly harvests in the fall and eight weekly harvests in the spring increased linearly with increasing total PAR (Fig. 4A). Fewer flowers or reduced fruit set under shade appeared to be responsible for most of the decrease in yields because total fruit number was reduced by reduced light levels more than mean single fruit weights (Table 3).

In Fall 1986, anthesis was delayed from 3 days under $30 \%$ shade to 14 days under $73 \%$ shade compared to plants grown in full-sun (Table 3). In Spring 1987, anthesis was delayed 3 days relative to full sunlight under all shade levels. These delays in anthesis caused corresponding delays in time to first fruit harvest. First harvest in the full-sun plots began 4 weeks after transplanting in the fall, but 6 weeks after transplanting in the spring.

Regardless of shade level, the peak harvest occurred 11 weeks 

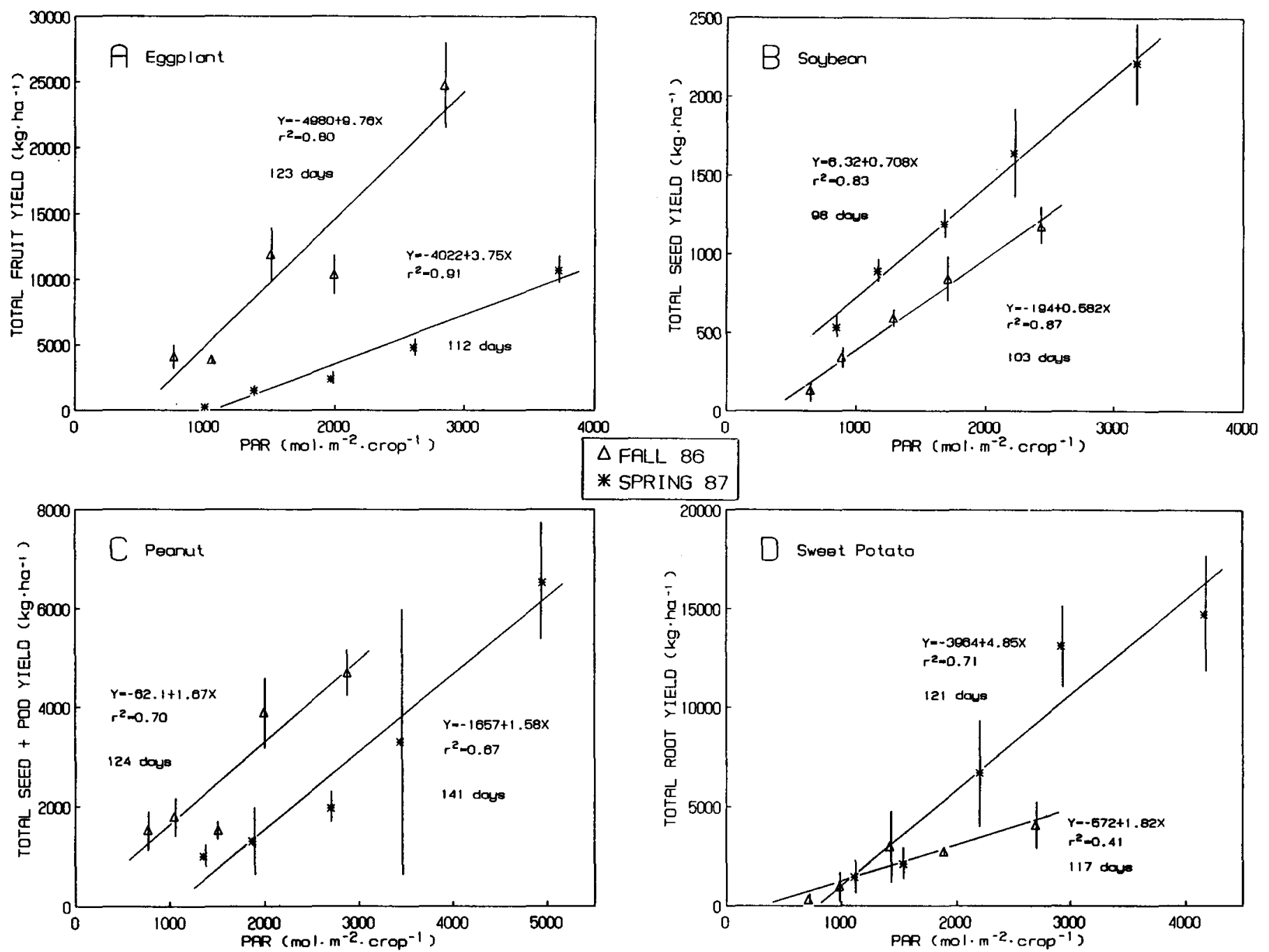

Fig. 4. Total fruit yield of 'Waimanalo Long' eggplant (A), total seed yield of 'Kahala' soybean (B), total seed + pod yield of 'Jumbo Virginia' peanut $(\mathbf{C})$, and total root yield of 'Waimanalo Red' sweet potato (D) grown during Fall 1986 and Spring 1987 as a function of accumulated photosynthetically active radiation (PAR) per crop cycle. Days indicated is length of crop cycle. Vertical bars $=$ SE.

Table 3. Cumulative fruit number, mean single fruit weight, and date of anthesis of 'Waimanalo Long' eggplant grown during Fall 1986 and Spring 1987 under five shade levels. ${ }^{2}$

\begin{tabular}{|c|c|c|c|c|c|c|}
\hline \multirow{3}{*}{$\begin{array}{l}\text { Percent } \\
\text { shade }\end{array}$} & \multirow{2}{*}{\multicolumn{2}{|c|}{$\begin{array}{l}\text { Cumulative fruit } \\
\text { no. }\left(\times 10^{3} / \mathrm{ha}\right)\end{array}$}} & \multirow{2}{*}{\multicolumn{2}{|c|}{$\begin{array}{l}\text { Mean single } \\
\text { fruit wt (g) }\end{array}$}} & \multicolumn{2}{|c|}{$\begin{array}{l}\text { Date of } \\
\text { anthesis }\end{array}$} \\
\hline & & & & & \multirow{2}{*}{$\begin{array}{l}\text { Nov. } \\
1986\end{array}$} & \multirow{2}{*}{$\begin{array}{l}\text { Apr } \\
198\end{array}$} \\
\hline & Fall 1986 & Spring 1987 & Fall 1986 & Spring 1987 & & \\
\hline 0 & $458 \pm 51$ & $239 \pm 19$ & $54 \pm 1.9$ & $45 \pm 1.7$ & 4 & 7 \\
\hline 30 & $241 \pm 35$ & $108 \pm 15$ & $43 \pm 1.5$ & $45 \pm 1.3$ & 7 & 10 \\
\hline 47 & $218 \pm 22$ & $57 \pm 10$ & $54 \pm 4.0$ & $44 \pm 0.8$ & 13 & 10 \\
\hline 63 & $92 \pm 2$ & $42 \pm 9$ & $42 \pm 1.7$ & $37 \pm 0.7$ & 15 & 10 \\
\hline 73 & $96 \pm 20$ & $12 \pm 3$ & $43 \pm 2.9$ & $29 \pm 3.7$ & 18 & 10 \\
\hline \multicolumn{7}{|c|}{ Statistical significance } \\
\hline Linear & $* *$ & $* *$ & $*$ & $* *$ & & \\
\hline Quadratic & NS & $* *$ & NS & * & & \\
\hline
\end{tabular}

${ }^{2}$ Means $\pm 95 \%$ confidence interval.

NS,*,**Nonsignificant or significant at $P=0.05$ or 0.01 , respectively.

after transplanting in the fall and 10 weeks after transplanting in the spring. Likewise, the final harvest, determined when fruit yields and quality had declined sharply, was made 14 and 13 weeks after transplanting for the fall and spring experiments, respectively (Table 1). This decline occurred in the same week in all shade levels in both experiments. A 3-week longer harvest 


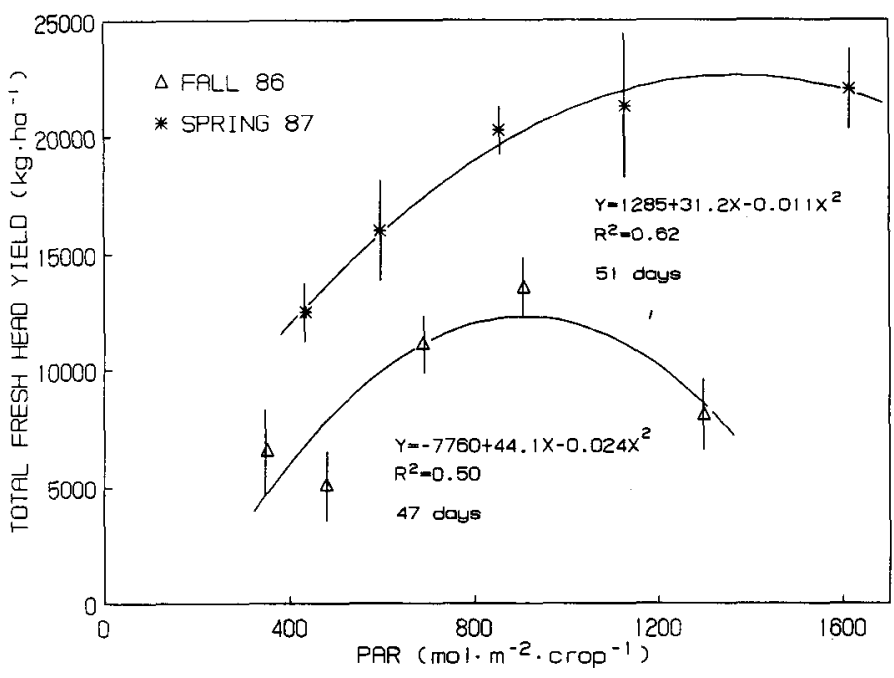

Fig. 5. Total fresh head weight yield of 'Green Mignonette' lettuce grown during Fall 1986 and Spring 1987 as a function of accumulated photosynthetically active radiation (PAR) per crop cycle. Days indicated is length of crop cycle. Vertical bars = SE.

in Fall 1986 produced higher eggplant yields overall in this experiment than in Spring 1987. Full-sun yields for Fall 1986 were similar to yearly Oahu averages of $26.6 \mathrm{t} \cdot \mathrm{ha}^{-1}$, while Spring 1987 yields were only $40 \%$ of those averages (Hawaii Agricultural Statistics Service, 1986).

Higher yields in Fall 1986 than in Spring 1987 plantings may rest on the fact that 'Waimanalo Long' eggplant was bred in Hawaii and is adapted to the warmer fall temperatures (Tanaka and Sakuoka, 1973). The mean air maximum for the first half of the crop cycle of eggplant was 29.3C during Fall 1986, but 27.7C during Spring 1987, while the mean minima were 22.4C in Fall 1986 and 18.3C in Spring 1987 for the first half of each crop cycle (Fig. 1).

Soybean yields also were very sensitive to shade (Fig. 4B). These results contrast with results from shading studies carried out with 'Kahala' soybean in Paia, Hawaii, where similar seed yields in the no-shade plots and $30 \%$ shade plots were obtained, with darker shade reducing yields (Eriksen and Whitney, 1984). Soybean seed yields were higher in the spring than in the fall. Lower yields of 'Kahala' soybean have been reported previously for the period from Aug. to Dec. (Beard et al., 1980; B. Beard, S. Geng, and R. Hartmann, unpublished data; Eriksen and Whitney, 1984). In contrast to yields, phenology of the soybean plants in both the fall and spring trials was not influenced by shading. The four-node stage, anthesis, green-bean stage, and harvest maturity all occurred at the same time in all shade treatments.

Peanut total seed-plus-pod yields also decreased with decreasing total PAR received (Fig. 4C). Development also was delayed by shade stress, with anthesis delayed 3 days under $47 \%$ shade and 5 days under $63 \%$ and $73 \%$ shade in Fall 1986. In Spring 1987, anthesis was delayed 2 days under $30 \%$ and $47 \%$ shade, and 12 days under $63 \%$ and $73 \%$ shade. This delay in anthesis caused corresponding delays in time to harvest (Table 1 ). Peanut is very sensitive to temperatures $>25 \mathrm{C}$, which cause reduced vegetative and reproductive growth (Hang et al., 1984; Ketring, 1984). The lower yields of peanut during the fall compared to the spring planting may have been due to the higher temperatures experienced at the time (Fig. 1).
Total root yields of 'Waimanalo Red' sweet potato also were directly reduced by shading in both seasons (Fig. 4D). As with soybean and peanut, sweet potato yields were higher in the spring than in the fall. Fall 1986 yields under full-sun were only $33 \%$ of seasonal state averages, while Spring 1987 yields were similar to seasonal state averages of $11.6 \mathrm{t} \cdot \mathrm{ha}^{-1}$ (Hawaii Agricultural Statistics Service, 1986). These yield differences between seasons probably were due to premature harvesting in the fall. Harvesting more-mature plants in Spring 1987 resulted in the recovery of more, and larger, roots than in Fall 1986 (Table 2). Nevertheless, similar trends of yields, root number, and root quality (mean single root size) in response to shade were observed in both seasons, although the negative impacts of shading were more dramatic when plants were harvested more-mature. Both mean single root weight and number of roots were reduced with increased shading for any one harvest (Table 2). 'Waimanalo Red' appears to be less shade-tolerant than other reportedly shade-adapted cultivars whose root yields were equal to or greater than full-sun plot yields when grown under $20 \%$ shade (Martin, 1985).

In contrast to the other crops, lettuce yields were not significantly reduced by moderate shading (Fig. 5). On the contrary, reducing total PAR by $30 \%$ appeared to be beneficial to the fall crop, increasing yields $40 \%$ relative to the crop grown in opensun. Yields were $27 \%$ higher in the $47 \%$ shade treatment compared to the full-sun treatment. Heavy shade $(63 \%$ and $73 \%$ shade) reduced not only total yields, but also the quality of the heads by producing loose heads with fewer leaves.

The beneficial effect of $30 \%$ and $47 \%$ shade on 'Green Mignonette' lettuce during the fall was possibly due to an alleviation of high temperature and/or water stress while still providing enough radiant energy for maximum $\mathrm{Pn}$. Previous shading studies with vegetable crops grown under high insolation have produced similar conclusions (Glenn et al., 1984; Mattei et al., 1973; Smith et al., 1984). 'Green Mignonette' lettuce is known to perform better under temperatures lower than those predominating during the fall crop (Hartmann et al., 1978). Mean air maximum for the growing period of lettuce ( 7 weeks) in the fall was $29.3 \mathrm{C}$ and $27.9 \mathrm{C}$ during the spring (Fig. 1). Mean minima were $22.2 \mathrm{C}$ in the fall and $18.4 \mathrm{C}$ in the spring.

During Spring 1987, lettuce yields were much higher at all shade levels than during Fall 1986, presumably because of cooler temperatures. Yields in the spring under $30 \%$ and $47 \%$ shade were as high as with no shade, although no enhancement of yields by these levels of shade was observed. Thus, while shade may not be beneficial, neither is it detrimental during cooler seasons. Low-quality, lightweight heads were produced under $63 \%$ and $73 \%$ shade, as was observed in the fall. Seasonal differences in yield usually occur in commercial lettuce production, with Oahu lettuce yields in November being $16 \%$ lower than those harvested in April (Hawaii Agricultural Statistics Service, 1986). The average yield over both experiments of the full-sun plots, $15.0 \mathrm{t} \cdot \mathrm{ha}^{-1}$, was slightly higher than the yearly island average of $14.0 \mathrm{t} \cdot \mathrm{ha}^{-1}$. Growth rate was similar under all shade treatments during both seasons, with all plants reaching maturity simultaneously. Plants had begun to bolt 1 week after harvest maturity, regardless of shade level.

The results of this study indicate that yields of 'Waimanalo Long' eggplant, 'Kahala' soybean, 'Jumbo Virginia' peanut, and 'Waimanalo Red' sweet potato are likely to be reduced by any amount of shading, while yields of 'Green Mignonette' lettuce may benefit from production under light (30\% to $47 \%$ ) shade. 
These data provide estimates of the quantitative relationships between yields and total solar radiation received for these crops, which should permit better resolution of crop responses to additional important variables, such as water and nutrient availability, in an intercropping environment. The potential for increasing yields of 'Green Mignonette' by producing the crop in shade structures also warrants further study. The high value of this crop and the small size of typical farms producing it in Hawaii makes the construction of structures for this purpose a reasonable possibility.

\section{Literature Cited}

Beard, B.H., J.C. Gilbert, and T. Sekioka. 1980. Seasonal variation in the performance of soybeans in Hawaii. Crop Sci. 20:163-165.

Boardman, N.K. 1977. Comparative photosynthesis of sun and shade plants. Annu. Rev. Plant Physiol. 28:355-377.

Bowes, G., W.L. Ogren, and R.H. Hageman. 1972. Light saturation, photosynthesis rate, RUDP carboxylase activity, and specific leaf weight in soybeans grown under different light intensities. Crop Sci. 12:77-79.

Eriksen, F.I. and A.S. Whitney. 1984. Effects of solar radiation regimes on growth and $\mathrm{N}_{2}$ fixation of soybean, cowpea, and bushbean. Agron. J. 76:529-535.

Glenn, E.P., P. Cardran, and T.L. Thompson. 1984. Seasonal effects of shading on growth of greenhouse lettuce and spinach. Scientia Hort. 24:231-239.

Hang, A.N., D.E. McCloud, K.J. Boote, and W.G. Duncan. 1984. Shade effects on growth, partitioning, and yield components of peanuts. Crop Sci. 24:109-115.

Hartman, R., Y. Nakagawa, and R. Sakuoka. 1978. Lettuce. Hawaii Coop. Ext. Serv., College of Trop. Agr. and Human Resources,
Honolulu. Home Garden Veg. Ser. 2.

Hawaii Agricultural Statistics Service. 1986. Statistics of Hawaiian agriculture 1986. Hawaii Dept. of Agr. Marketing Division and USDANASS, Honolulu.

ICRISAT. 1981. Proceeding of the International Workshop on Intercropping. 10-13 Jan. 1979. Hyderabad, India. Intl. Crops Res. Inst. for the Semi-Arid Tropics, Pantancheru, India.

Jones, C.A. 1985. Experimental design and data collection procedures for IBSNAT. IBSNAT. Tech. Rpt. 1.

Ketring, D.L. 1984. Temperature effects on vegetative and reproductive development of peanut. Crop Sci. 24:877-882.

Knight, S.L. and C.A. Mitchell. 1983. Stimulation of lettuce productivity by manipulation of diurnal temperature and light. HortScience 18:462-463.

Martin, F.W. 1985. Differences among sweet potatoes in response to shading. Trop. Agr. (Trinidad) 62:161-165.

Mattei, F., L. Sebastiani, and D. Gibbon. 1973. The effect of radiant energy on growth of Lactuca sativa L. J. Hort. Sci. 48:311-313.

Meek, D.W., J.L. Hatfield, T.A. Howell, S.B. Idso, and R.J. Reginato. 1984. A generalized relationship between photosynthetically active radiation and solar radiation. Agron. J. 76:939-945.

Nishimoto, R.K., R.L. Fox, and P.E. Parvin. 1977. Response of vegetable crops to phosphorus concentrations in soil solution. J. Amer. Soc. Hort. Sci. 102:705-709.

Smith, I.E., M.J. Savage, and P. Mills. 1984. Shading effects on greenhouse tomatoes and cucumbers. Acta Hort. 148:491-500.

Stelly, M. (ed.) 1983. Multiple cropping. Amer. Soc. Agron. Spec. Publ. 27. Madison, Wise.

Tanaka, J.S. and R.T. Sakuoka. 1973. Eggplant. Home and Garden Vegetable Ser. 13. Coop. Ext. Serv., College of Tropical Agriculture, Univ. Hawaii, Honolulu.

Wilkinson, L. 1986. SYSTAT: The system for statistics. SYSTAT, Inc., Evanston, 111 